\title{
The Role of Profitability in Mediating the Effect of Dividend Policy and Company Size on Company Value
}

\author{
Rio Monoarfa \\ Correspondence: Rio Monoarfa, M.Si in Economics and Business Faculty, State University of Gorontalo, Indonesia
}

Received: April 9, 2018

doi:10.11114/bms.v4i2.3274

\author{
Accepted: May 14, $2018 \quad$ Online Published: May 16, 2018 \\ URL: https://doi.org/10.11114/bms.v4i2.3274
}

\begin{abstract}
The purpose of this research is to analyze the effect of dividend policy and company size on profitability and company value of consumer goods company in Indonesia Stock Exchange (IDX). The population of this research is consumer goods companies in Indonesia Stock Exchange in the year of 2014-2016 amounted to 45 companies. Sampling is done by saturation sampling method in which all members of population are used as sample. The data analysis of this research uses method of structural equation added by PLS (Partial Least Square) approach. The result of the research shows that dividend policy has negative effect on profitability, while company size does not give any effect on profitability. Dividend policy, company size and profitability variable have an effect on company value. Profitability can not mediate the effect of dividend policy on company value but it can mediate the effect of company size on company value.
\end{abstract}

Keywords: dividend policy, company size, profitability and company value

\section{Introduction}

Consumer goods industry in Indonesia is growing more positively in line with economic growth. Indonesia's economic growth causes an increase in people's welfare that can trigger a rise in demand for consumer goods products. This condition opens opportunities for increased consumption of consumer goods products that ultimately promote the growth of consumer goods industry. Continuous positive growth in the consumer goods industry will surely help to increase the value of investments in this field. (Bahar, 2011). Increase in investment value is followed by an increase in corporate value.

Corporate value is very important because high company value will be followed by high shareholder wealth (Gapenski, 1996). The higher the stock price, the higher the company value. Managers are required to make decisions that consider all stakeholders in maximizing the company value in the long term because the manager will be assessed for his performance based on the success of achieving the goal (Jensen, 2001). Company value can be seen from Price Book Value (PBV) which is a comparison between stock price with book value per share (Ang, 2002). Good companies generally have a larger PBV ratio of one (>1), which indicates that the stock market value is greater than the book company value. The higher the PBV ratio, the higher the rating of investors compared to the funds invested in the company so that the greater the opportunity of investors to buy shares of the company (Ang, 2002).

The following table shows the average value of the development of Price Book Value (PBV) of consumer goods companies in Indonesia Stock Exchange (IDX) listed on the Indonesia Stock Exchange in the period of 2012 to 2016.

Table 1. Average Price Book Value (PBV) at Consumer Goods Companies Listed on IDX

\begin{tabular}{c|c|c|c|c|c}
\hline Rasio & $\mathbf{2 0 1 2}$ & $\mathbf{2 0 1 3}$ & $\mathbf{2 0 1 4}$ & $\mathbf{2 0 1 5}$ & $\mathbf{2 0 1 6}$ \\
\hline PBV & 5.48 & 5.46 & 5.38 & 2.22 & 5.58 \\
\hline
\end{tabular}

Source: processed ICMD

Based on Table 1, the average Price Book Values (PBV) of consumer goods companies is greater $(>1)$ indicating that the market value of shares is greater than the book company value, so the greater the opportunity for investors to buy shares of the company. This is a reflection of the high value consumer goods companies although in 2015 there was a significant decline. The phenomenon about the decline in PBV values is interesting to be reviewed in knowing the factors that affect the company value.

The company value can be seen from the ability of the company to pay its dividend. The number of dividends is divided 
as it can affect the stock price. If the dividend paid is high then the stock price tends to be high so that the company value is also high.However, if the dividends paid is small, then the price of company stock is also low. Thus, large dividends will increase the company value (Harjito and Martono, 2010: 115).

Dividend payments are part of the company's monitoring. Companies tend to pay bigger dividends if insiders have a lower share proportion. Paying dividends to shareholders will reduce the sources of funds controlled by managers, thereby reducing managers' powers and making dividend payouts similar to the monitoring of the market capital that occurs when companies acquire new capital (Rozeff, 1982 andEasterbook, 1984).

Bird in the Hand Theory suggests that there is a relationship between company value and dividend policy, where the company value will be maximized by the high dividend payout ratio, as investors assume that dividend risk is not as big as the risk of increase in capital value (Gordon and Lintner, 1956). Investors prefer profits in the form of dividends rather than the expected returns from capital appreciation.

Alonso et al. (2005) found the evidence that dividend affects company value. Amidu (2007) found that dividend policy had a positive effect on company value seen from company performance (ROA) .Qureshi (2007) showed that adequate dividend policy can achieve the goal of maximizing corporate value. Ghosh and Ghosh (2008) found that dividend policy is positively related to company value. Different results are shown by Kapoor (2006) that dividend is not significantly related to company value.

The company size is considered capable of affecting the company value Because the larger the size or scale of the company it will be easier the company also obtain sources of funding both internal and external. Decisions concerning the company size will result in the share price of the company (Weston and Copeland, 2010: 13). In general, size can be interpreted as a comparison of the size or magnitude of an object. If this understanding is linked to a company or organization, then the company size can be defined as a comparison of the size or size of the business of a company or organization

The size of a company is a scale that can be classified as a small company by various means, including total assets, log size, stock market value, and so on. Basically the company size is only divided into categories of large company, medium-sized company, and small company. The determination of this company size is based on the total assets of the company (Machfoedz, 1994: 87).

Companies with large assets show that the company has reached the maturity stage where in this stage the company cash flow has been positive and is considered to have a good prospect in a relatively long period of time. In addition, it also reflects that the company is relatively more stable and more able to generate profit compared to companies with small total assets (Indriani, 2005). Usually large companies have large assets or value. Theoretically, larger companies have greater certainty than small companies have lower certainty regarding their future prospects. It can help investors predicting the risks that may occur if investing in the company (Yolana and Martani, 2005).

Cheng, Liu and Chien (2001) concluded that the size of individual company affects the value of companys listed on the Chinese stock exchange. Paranita, (2007) and Sujoko and Soebiantoro (2007) concluded that company size has a positive effect on company value. Obradovich and Gill (2013) concluded that company size has a positive and significant effect on the value of companies listed on the New York Stock Exchange. Purnomosidi.L. et al (2014) concluded that company size has a positive effect on the value of real estate companies in Indonesia Stock Exchange. Siahaan, U. Marius, et al (2014) showed that company size positively affects the value of manufacturing companies listed on the Indonesia Stock Exchange. Different results are shown by Gill and Mathur (2011) to prove that larger company size (a large number of directors) have a negative impact on the value of manufacturing companies in Canada. Machfoeds and Hamonangan (2006) concluded that company size does not show non linear relation to company value.

The result of empirical study on dividend policy and company size to company value still gives gap to be reviewed and to cover the gap, it is necessary to mediate the variable that is profitability.

One important indicator for investors in assessing the prospects of the company in the future is to see how far the growth of corporate profitability (Tandelilin, 2001). High profitability reflects the company's ability to generate high returns for shareholders. The greater the profit the greater the company ability to pay its dividends and this has an impact on the increase in corporate value. With a high profitability ratio owned by a company, it will attract investors to invest in the company.

Information to the market or investors about the circumstances and prospects of the company can be seen from the dividend policy. Company dividend policy becomes a means to provide information to the market or investors regarding the company's financial circumstances. Signaling theory states that the increase of dividend payments by companies to investors is considered as good news because it indicates conditions and prospects of the company in good circumstances, resulting in positive reactions by investors. Djanthan (2013), Fauzi and Suhadak (2015) concluded that 
dividend policy has a significant and positive effect on profitability.

Companies that are able to increase their corporate profits will have the opportunity to expand. Expansion is an active action to expand and enlarge the company. Companies that have larger sizes have an effect on increasing the profitability of the company. Bartalola (2013), Dogan (2013) and Niresh and Velnampy (2014) indicated that company size has a significant positive effect on profitability

One important indicator for investors in assessing the prospects of the company in the future is to see how far the growth of corporate profitability (Tandelilin, 2001). High profitability reflects the ability of companies in generating high profits for shareholders. The greater the profits derived the greater the company value. With a high profitability ratio, a company will attract investors to invest in the company. Chowdhury, Anup and Chowdhury, S. Paul (2010), Rizqia, et al. (2013) concluded that profitability has a positive effect on company value.

Based on this, there is a gap for re-examination of the effect of dividend policy and company size on the company value with profitability as a mediation variable. This research is expected to be one of the empirical study materials regarding profitability as a mediator influencing dividend policy and company size on company value

\section{Literature Review}

\subsection{Company Value}

According to Keown (2003: 74) company value is the market value of debt securities and outstanding corporate equity. The company value is the perception of investors to the success rate of companies that are often associated with stock prices (Sujoko and Soebiantoro, 2007). High stock prices make the company's value is also high. High corporate value will make the market believe not only in the company's current performance but also on the future prospects of the company. Corporate value is often proxied with price to book value. Reilly and Brown (2000) suggested that PBV ratios can be used for all types of companys because book value can be a rational measure to assess companys. Similarly, the ratio of price to book value can be used to compare companys that have the same accounting standards in an industry sector. Even these measurements can be applied to companies with negative earnings or even negative cash flow. The existence of PBV is very important for investors to determine the investment strategy in the capital market because through price book value, investors can predict stocks that overvalued or undervalued. Price book value illustrates how much the market appreciates the value of a company's stock book. Companies that run well, generally have a price book value ratio above one, which reflects that the stock market value is greater than the value of his book. The high price book value reflects the level of prosperity of shareholders, the prosperity for shareholders is the main objective of the company (Weston and Brigham, 2000: 71).

\subsection{Dividend Policy}

The dividend policy is an integral part of the company's funding decisions. The dividend policy is a decision on how much current profit will be paid as a substitute dividend from invested investments and how much is retained for reinvestment within the company (Brigham and Houston, 2010: 32). If the company chooses to distribute profits as dividends, it will reduce the profit to be retained and subsequently reduce the internal funding source. Conversely, if the company chooses to hold the profit earned, then the ability of the formation of internal funds will be even greater.

There are two conflicting theories about dividend policy that should be embraced by the company. First is the theory developed by Modligiani and Miller (1961) who stated that dividend policy is irrelevant. Modligiani and Miller (1961) also stated that with a particular investment decision, the dividend ratio distributed does not give any effect on the company's value. The essence of their opinion that dividend policy is irrelevant. According to Modligani and Miller (1961) as the main advocates of the theory of dividend irrelevance theory, the company value (stock price changes) is determined only by their basic ability to generate profits and business risks. In other words, they argue that the value of a company depends solely on profits generated by the asset rather than on how the profit is distributed between the dividend payments and the retained earnings.

On the other hand, Gordon and Lintner (1956), put forward the theory of bird in the hand. They argue that dividends will be less risky than capital increase, and therefore the cost of corporate equity will increase if dividends are reduced. Thus, a company can establish a high dividend payout ratio and offer a high dividend yield to minimize its capital costs. In addition, the dividend payout is a sign for investors, where huge dividend increases indicate that management is optimistic, while dividend declines indicate that management is pessimistic about the company's future. The company's dividend policy will attract interest from certain investors who are in agreement with the company's dividend policy

\subsection{Company Size}

Company size is a scale that can be classified as a small company by various means, including total assets, log size, stock market value, and so on. Basically, company size is divided into categories of large company, medium-sized 
company, and small company. The determination of company size is based on the total assets of the company (Machfoedz, 1994).

The company size can be measured using the total assets, sales, or capital of the company. One of the benchmarks that shows the company size is the size of the assets of the company. Company with large assets show that the company has reached the maturity stage where in this stage the company cash flow has been positive and is considered to have a good prospect in a relatively long period of time, but it also reflects that the company is relatively more stable and more able to generate profit compared to company with a small total of assets

\subsection{Profitability}

Profitability is the company's ability to generate profit. Profitability reflects the advantages of financial investment. Myers and Majluf (1984) argued that financial managers who use packing order theory with retained earnings as the first option in meeting financing and debt needs as a second option and issuing shares as a third option, will always increase profitability to improve earnings. Profitability ratio is a ratio to measure the ability of companies to earn profits in relation to sales, total assets and own capital (Sartono, 2008). This ratio is highly considered by prospective investors and shareholders as it relates to stock prices and dividends to be received.

Profitability serves as a benchmark in determining the alternative financing, but the way to assess the company's profitability is diverse and highly dependent on profits and assets or capital that will be compared from profits derived from operations or net profit after tax with own capital. The existence of various ways in the research profitability of a company is not surprising. As a result, there are some companies that have differences in determining an alternative to calculate profitability. The choice regarding which profitability will be used, the purpose is solely depend on the tool to measure the efficiency of capital use in the company concerned.

Profitability ratios can be measured from two approaches: sales approach and investment approach. The widely used measures are return on assets (ROA) and return on equity (ROE), profitability ratios measured by ROA and ROE reflect business attractiveness (bussines attractive). Return on asset (ROA) is a measure of the company's overall ability to generate profits with the total assets available within the company. ROA is used to see the level of efficiency of a company 's overall operations. The higher this ratio, the better the company is.

\section{Research Methods}

In accordance with the subject matter and research objectives, this research uses the pattern of explanation. Explanatory research is a study that intends to describe the effect between two or more variables, which is symmetrical, causal and reciprocal. The pattern of effect that will be revealed in this research is the effect of dividend policy and company size on profitability and value of consumer goods companies listed on the IDX in the period 2014-2016.

The unit of analysis in this study is Consumer Goods companies. The population is goods companies which are still active in Indonesia Stock Exchange (IDX) during 2014 until 2016 amounted to 45 companies. Sampling was done by saturated sampling method. According Sugiyono (2006) saturated sampling is a technique of sampling when all members of the population used as a sample.

The type of data used in this study is secondary data, ie the source of research data obtained indirectly or through intermediary media. Secondary data such as data in the form of corporate financial statements and data collection techniques used are documentation. Documentation is a method to obtain data by collecting data from existing literature. The source of this research data obtained from the site www.idx.go.id.

Operational definition of research variables is an explanation of each variable used in the study. Operational variable of this research can be seen on table 2 
Table 2. Operational variables used in reseacrh

\begin{tabular}{|c|c|c|}
\hline Variable & Proction & References \\
\hline dividend policy & $\begin{array}{l}\text { Dividend policy is measured using the following } \\
\text { indicators Dividend Pay Out Ratio/DPR. } \\
\text { Dividend Pay Out Ratio }=\frac{\text { dividen per share }}{\text { incomepershare }}\end{array}$ & $\begin{array}{l}\text { Brealey, Myers, Marcus } \\
\text { (2008: 82), Moeljadi (2006: } \\
\text { 54) }\end{array}$ \\
\hline Company’s size & $\begin{array}{l}\text { The company's size will be calculated using the } \\
\text { following formula: SIZE }=\ln \text { of total assets }\end{array}$ & $\begin{array}{l}\text { Cheng, Liu and Chien } \\
\text { (2001), Obradovich dan Gill } \\
(2013)\end{array}$ \\
\hline Profitabiliy & $\begin{array}{l}\text { Profitability ration can be measured using } \\
\text { Return on Assets }(\mathrm{ROA})=\text { Total Asset }\end{array}$ & $\begin{array}{l}\text { Brigham and Houston } \\
(2006: 109)\end{array}$ \\
\hline Company's value & $\begin{array}{l}\text { Company value can be measured using Price Book } \\
\text { Value } / \mathrm{PBV}=\frac{\text { Stock price per stock sheet }}{\text { Book value per stock sheet }}\end{array}$ & $\begin{array}{lr}\text { Weston dan } & \text { Brigham } \\
(2006: 115), & \text { Warsono } \\
(2003: 39), \text { Ross et al, } \\
(2008: 93)\end{array}$ \\
\hline
\end{tabular}

The method used in this study is Smart Partial Least Square (Smart PLS) 2.0 program. The PLS approach is used to test complex hypotheses by calculating the effect of exogenous variables on endogenous variables. Therefore, to conclude whether the research can prove the hypothesis, cut-off value ttable value $=1.96$.If $\mathrm{t}$ statistics on the tested path $\geq 1.96$, is used. Then, the exogenous variable affects on endogenous variables. Meanwhile, to prove the indirect effect it is done by comparing the total coefficient of effect with the coefficient of direct effect. If the total effect is greater than the direct effect, profitability may mediate the effect of dividend policy and company size on company value.

\section{Findings and Discussions}

\subsection{Testing of Structural Model or Inner Model}

The test of structural model or Inner Model is evaluated by looking at the value of R2 from the latent variable by using Geisser Q Square test, then it is continued by looking at the magnitude of the structural path coefficient. Estimation stability over structural line coefficients is evaluated by using t-statistical test obtained from bootstrapping procedure. Inner model test can be seen from R-Square value on equation between latent variables. R-Square calculation results can be seen on Table 3 .

Table 3. R-Square Calculation Results

\begin{tabular}{l|c}
\hline \multicolumn{1}{c|}{ Variable } & R-Square \\
\hline Profitability $\left(\mathrm{Y}_{1}\right)$ & 0,094 \\
\hline Company value $\left(\mathrm{Y}_{2}\right)$ & 0,406 \\
\hline
\end{tabular}

Based on the calculation on Table 3, Q-square measures how well the observation values generated by the model and also the estimated parameters (Ghozali, 2006). The Q-square value greater than zero (0) indicates that the model has a predictive relevance value, whereas Q-square less than zero (0) indicates that the model lacks predictive relevance. To determine the value of Q-square, the following formula is used:

$$
\left.Q^{2}=1-\left(\sqrt{1-R_{1}{ }^{2}}\right) *\left(\sqrt{1-R_{2}{ }^{2}}\right)\right)
$$

The calculation of Q-square using $R$-square on the above three models can be done as follows:

$$
\begin{gathered}
Q^{2}=1-(\sqrt{1-0,094}) *(\sqrt{1-0,406}) \\
Q^{2}=1-(0,952) *(0,771) \\
Q^{2}=0,266
\end{gathered}
$$

Based on the calculation of Q-square (Q2), the value of Q-square obtained is 0.266 . This figure can be interpreted that the research model can explain $26.6 \%$ contribution effect on dividend policy and company size variables to profitability and company value equal to $26.6 \%$. Therefore, more than 0 (zero) shows that model have predictive relevance.

\section{Structural Model Testing}

Hypothesis testing is done using structural equation method with PLS approach (Partial Least Square), by testing the significance of path coefficient in the model. The PLS approach is used to test complex hypotheses by calculating the effect of independent variables (exogenous) on a dependent variable (endogen). Therefore, to conclude whether the proven research hypothesis, it is done using cut-off value ttable value $=1.96$. Thus, if $t$ statistics on the tested path $\geq$ 1.96 , then the research hypothesis is proved. The results of these tests in detail can be seen on Table 4 
Table 4. Result of Hypotheses Testing

\begin{tabular}{|c|c|c|c|c|}
\hline \multirow[t]{2}{*}{ Variables Relationship } & & \multicolumn{3}{|c|}{ Causal effect } \\
\hline & T-Statistic & $\begin{array}{l}\text { Direct } \\
\text { Effect }\end{array}$ & $\begin{array}{l}\text { Indirect effect through } \\
\text { profitability }\end{array}$ & Total \\
\hline $\begin{array}{lll}\begin{array}{l}\text { dividend } \\
\text { profitability }\end{array} & \text { policy } & \text {-> } \\
\end{array}$ & 6.326 & -0.306 & - & -0.306 \\
\hline size $->$ profitability & 0.032 & 0.005 & - & 0.005 \\
\hline $\begin{array}{ll}\text { dividend policy } & \text {-> } \\
\text { company value } & \\
\end{array}$ & 4.616 & 0.434 & $(-0.306 \times 0.186)$ & 0.377 \\
\hline size -> company value & 3.759 & 0.540 & $(0.005 \times 0.186)=$ & 0.541 \\
\hline $\begin{array}{l}\text { profitability } \rightarrow \text { company } \\
\text { value }\end{array}$ & 2.081 & 0.186 & - & 0.186 \\
\hline
\end{tabular}

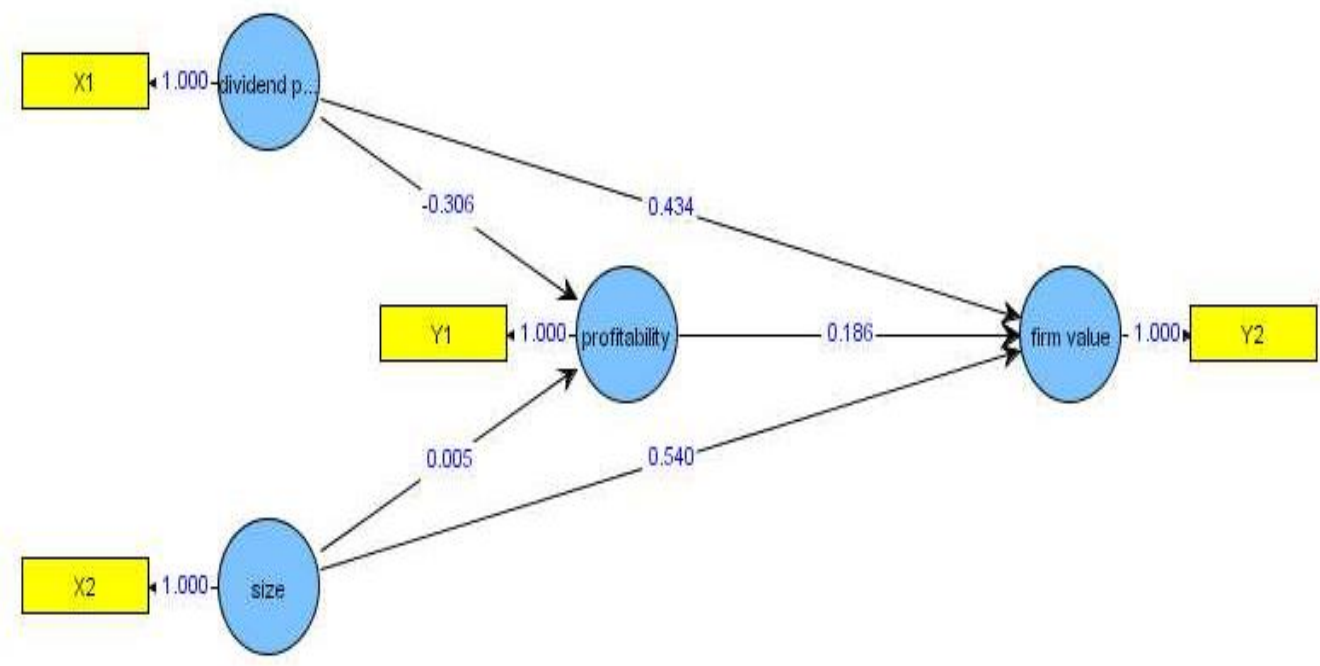

Figure 1. Coefficient of PLS Path

\subsection{The Effect of Policy Dividend on Profitability}

Based on the results of inferential statistical analysis, it shows that the dividend policy has negative effect on the implementation of -0.306 . This result shows that the increase of dividend pay out ratio decreases the return on assets by $30.6 \%$. This result can be explained that dividend policy is a decision to determine how much dividend should be distributed to shareholders. This policy stems from how management's treatment of corporate profits generated part of the net income after taxes were distributed to investors in the form of dividends and partly reinvested into the company in the form of retained earnings. Retained earnings are one of the most important sources of funds to finance asset growth, while dividends are cash flows paid to investors. Companies always want growth for one-party companies and can also pay dividends to investors. On the other hand, but these two goals are always at odds. It is said to be contradictory because the higher the dividend payout ratio (DPR) set by a company, the less profit the company will need to be reinvested in the company. This result is not in line with the opinion of Ajanthan (2013), Fauzi and Suhadak (2015) stating that dividend policy has a significant and positive effect on profitability.

\subsection{The Effect of Company Size on Profitability}

Company size does not give effect to profitability with path coefficient of 0.005 . This result shows that increase of total assets can increase return on assets only equal to $0.5 \%$. The effect is not significant indicating that company size is not one of the main variables that can give effect to profitability significantly. This is because the size of a large company can not guarantee the profitability of the company is high, because large companies may not dare to make new investments related to expansion before obligations (debt) is paid off .. These results are not in accordance with the opinion from Babalola (2013), Dogan (2013) and Niresh and Velnampy (2014) showing that company size has a significant positive effect on profitability

\subsection{The Effect of Dividend Policy on Company Value}

Based on the results of inferential statistical analysis, it obtained evidence that the dividend policy has a positive and 
significant effect on the company value with path coefficient of 0.434 . This result shows that the increase of dividend pay out ratio can increase Price Book Value by $43.4 \%$. Dividend policy is a financial decision made by the company. The profits earned will be distributed to shareholders or held as retained earnings. Dividend policy often creates a conflict of interest between the management of the company and the investor. The dividend payout made by the company is considered to be a positive signal by investors to invest because investors prefer a definite return on their investment. Companies that distribute dividends will attract investors to invest. With so many investors buying stocks it will raise the stock price so it is able to increase the company value.

These findings are supported by the Bird in the Hand Theory proposed by Gordon and Lintner (1956), suggesting that there is a relationship between company value and dividend policy, where the company value will be maximized by a high dividend payout ratio, as investors assume that the dividend risk is not risk increase in capital value. Investors prefer profits in the form of dividends rather than the expected returns from capital appreciation.

The results of this study support the study conducted by Alonso et al (2005) who found the evidence that dividend affects company value.Mohammed Amidu (2007) found that dividend policy had a positive effect on company value seen from company performance (ROA) .Muhammad Azeem Qureshi (2007) indicated that an adequate dividend policy can achieve the goal of maximizing cormpany value. Ghosh and Ghosh (2008) found that dividend policy is positively related to company value.

\subsection{The Effect of Company Size to Company Value}

Based on the results of inferential statistical analysis, it obtained evidence that the company size is considered capable of affecting the compny value. In this case, the larger the size or scale of the company, the easier it is to obtain sources of funding both internal and external. Companies with large assets show that the company has reached the maturity stage where in this stage the company's cash flow has been positive and is considered to have a good prospect in a relatively long period of time, but it also reflects that the company is relatively more stable and more able to generate profit compared to companies with a small total of assets.

With the larger company size, there is a tendency for more investors to pay attention to the company. This is because the big companies tend to have more stable conditions. The company's stability attracts investors to own the company's shares. Conditions are the cause of rising stock prices of companies in the capital market. Investors have great expectations of large companies. Investor's expectation is in the form of acquisition of dividends from the company. Increased demand for stocks of companies will be able to spur on the increase in stock prices in the capital market. The increase indicates that the company is considered to have greater "value"

Theoretically, larger companies have greater certainty than small companies which have more uncertainties regarding their future prospects. It can help investors to predict the risks that may occur if they invest in the company (Yolana and Martani, 2005).

The results of this study support the study conducted by Cheng, Liu and Chien (2001) concluded that the size of individual company affects the value of companys listed on the Chinese stock exchange. Paranita, (2007) and Sujoko and Soebiantoro (2007) concluded that company size positively affects company value. Obradovich and Gill (2013) concluded that company size has a positive and significant effect on the company value listed on the New York Stock Exchange. Purnomosidi.L. (2014) concluded that company size has a positive effect on the value of real estate companies on the Indonesia Stock Exchange (IDX). Siahaan, U. Marius, et al (2014) showed that company size positively affects the company value listed on the Indonesia Stock Exchange (IDX).

\subsection{The Effect of Profitability on Company Value}

Based on the results of statistical analysis in this study, it was found that profitability has a significant positive effect on the company value. It shows that the higher profitability, the higher the company value. The higher the company ability to generate profits, it will raise the company value as indicated by the increase in the company's stock price. Companies that have large profitability every year, tend to be in demand by many investors. The investors think that companies that have big profits will generate a large return as well. This is captured by investors as a positive signal from the company, which will increase investor confidence and will facilitate the company's management to attract capital in stock.

The higher profitability of the company will also increase earnings per share (EPS or earnings per share) of the company. An increase in EPS will make investors interested to invest their capital by buying the company's shares. This condition leads to a positive relationship between profitability with stock prices where high stock prices will affect the company value.

In line with the opinion of Weston and Brigham (2001) which states that profitability measured by a high ROA reflects a good corporate position so that the value given to the market reflected in the stock price of the company will also be good. The results of this study support the study conducted by Paranita (2007), Chowdhury, Anup and Chowdhury, S. 
Paul (2010), Rizqia, et al (2013) concluded that the level of profitability has a positive effect on the company value.

\subsection{The Effect of Policy Dividend on Company Value through Profitability}

Based on the results of the analysis, it shows that profitability can not mediate the effect of dividend policy on corporate value. It means dividend policy directly affects the company value. This result shows that dividend policy is a very important decision in the company. This policy will involve two parties with different interests: the first party, the shareholders and the second party, the management of the company itself. The company's management has two alternative treatments on net income after tax or EAT (earnings after tax). The two alternatives are divided into shareholders in the form of dividends and reinvested into the company as retained earnings.

The amount of dividends distributed by companies can affect stock prices because investors prefer returns that are derived from dividends compared to capital gains. In other words, investors prefer profits in the form of dividends rather than the expected returns from rising capital values. Bird in the hand theory states that shareholders prefer high dividends because they have high certainty compared to capital gains. Companies that provide dividends constantly and tend to increase will provide a positive sentiment to investors. This impact on increasing the company value.

\subsection{The Effect of Company Size on Company Value through Profitability}

Based on the results of the analysis, it shows that profitability can mediate the effect of company size on the company value, which means company size can increase profitability which ultimately gives an impact on the effort in increasing company value. A large company asset will signal that the company has good prospects. Large companies tend to be better known to the public than small companies, as they are better known by the society for their information compared to smaller companies (Nurhasanah, 2012). The information available in those markets can be used as an analysis of investors in determining investment decisions and provide control to know the condition of company. Large companies have access to capital markets making it easier to obtain additional funds so it is able to increase the profitability of a company. The higher profitability of the company, the higher earnings per share (EPS or earnings per share) the company will get. An increase in EPS will make investors interested in investing their capital by buying the company's shares. This condition leads to a positive relationship between profitability with stock prices where high stock prices will affect the company value.

\section{Conclusion}

The result of the research shows that dividend policy has negative effect on profitability, while company size does not give any effect on profitability. Dividend policy, company size, and profitability variables affect company value. Profitability can not mediate the effect of the dividend policy on corporate value but it can mediate the effect of company size on company value. The results of this study are expected to provide input for investors and prospective investors in making investment decisions oriented to stocks that have high dividend, large corporate size, and and high profitability.

\section{References}

Abdolkhani, H., \& Jalali, R. (2013). Effect of managerial ownership concentrated on firm return and value: Evidence from Iran Stock Market. International Journal of Academic Research in Accounting, Finance and Management Sciences, 3(1).

Adekunle, A. O., \& Kajola, S. O. (2010). Capital Structure and FirmPerformance: Evidence from Nigeria. European Journal of Economics, Finance and Administrative Sciences. ISSN 1450-2275 Issue 25

Ajanthan, A. (2013). The Relationship between Dividend Payout and Firm Profitability: A Study of Listed Hotels and Restaurant Companies in Sri Lanka, International Journal of Scientific and Research Publications, 3(6).

Alonso, P. A., Félix J. L., Iturriaga, \& Juan, A. R. S. (2005). Financial Decisions and Growth Opportunitites: a Spanish Firm's. Journal Financial Economics, 15, 391-407.

Amidu, M., \& Abor, J. (2011). Determinants of dividend payout ratios in Ghana.The Journal of Risk Finance, 7(2), 136-145. https://doi.org/10.1108/15265940610648580

Ang, R. (1997). Buku Pintar Pasar Modal Indonesia. Mediasoft Indonesia: Jakarta

Babalola, A. Y. (2013). The Effect of Firm Size on Firms Profitability in Nigeria, Journal of Economics and Sustainable Development, 4(5), 90-94.

Brealey, R. A., \& Stewart, C. M. (2004), Principles of Corporate Finance. $7^{\text {th }}$ Edition, McGraw-Hill Companies, inc.

Brigham, E. F., \& Joel, F. H. (2010). Fundamental of Financial Management, Tenth Edition, Thomson, South Western.

Cheng, Y. S., Liu, Y. P., \& Chien, C. Y. (2010). Capital structure and firm value in China: A panel threshold regression 
analysis. African Journal of Business Management, 4(12), 2500-2507.

Chowdhury, A., \& Chowdhury, S. P. (2010). Impact of Capital Structure on Firm's Value: Evidence from Bangladesh. Business and Economic Horizons, 3(3), 111-122. https://doi.org/10.15208/beh.2010.32

Doğan, M. (2013). Does Firm Size Affect The Firm Profitability? Evidence from Turkey. Research Journal of Finance and Accounting, 4, 53-59.

Fauzi, M. N., \& Suhadak. (2015). Pengaruh Kebijakan Dividen dan Pertumbuhan Perusahaan Terhadap Struktur Modal dan Profitabilitas (Studi pada Sektor Mining yang Terdaftar di Bursa Efek Indonesia Periode 2011-2013). Jurnal Administrasi Bisnis (JAB), 24(1).

Gapensi, B. (1996). Intermediate Financial Management, Fifth Edition, TheDryden Press, NewYork.

Ghosh, S., \& Gosh, A. (2008). Do Leverage, Dividend Policy and Profitability influence the Future Value of Firm? Evidence from India.Finance e Journal. https://doi.org/10.2139/ssrn.1158251

Gill, A., \& Neil, M. (2011). Factors that Influence Financial Leverage of Canadian Firms. Journal of Applied Finance \& Banking, 1(2), 19-37.

Gordon, M., \& John, L. (1956). Distribution of Income of Corporations Among Dividend, Retained Earning and Taxes, The American Economic Review, May.

Harjito, D. A., \& Martono. (2010). Manajemen Keuangan, Ekonisia Kampus Fakultas Ekonomi UII,Yogyakarta.

Jensen, M. C. (2001). Value Maximization, Stakeholder Theory, And The Corporate Objective Function, Journal of Applied Corporate Finance, Morgan Stanley, 14(3), 8-21.

Keown, A. J. (2003). Basic Financial Management, Alih Bahasa, Chaerul D. dan Dwi Sulisyorini, Dasar-Dasar Manajemen Keuangan, Buku Kedua, Salemba Empat, Jakarta.

Machfoedz, M. (1994). Financial Ratio Analysis and The Predictions of Earnings Changes in Indonesia, 114 -137.

Machfoedz, M., \& Hamonangan. (2006). Mekanisme Corporate Governance, Kualitas Laba dan Nilai Perusahaan, Simposium Nasional Akuntansi 9 Padang

Modigliani, F., \& Miller, M. (1963). Corporate Income Taxses and The Cost of Capital: A Correction, American Economic Review, 53(June), 433-443.

Moeljadi. (2006). Manajemen Keuangan Pendekatan Kuantitatif dan Kualitatif, BPFE: Yogyakarta

Myers, S. C., \& Majluf, N. S. (1984). Corporate Financing and Investment Decisions When Firms Have Information That Investors do Not Have. Journal of Financial Economics, 187-221. https://doi.org/10.1016/0304-405X(84)90023-0

Niresh, J. A., \& Velnampy, T. (2014). Firm Size and Profitability: A Study of Listed Manufacturing Firms in Sri Lanka. Sri Lanka: University of Jaffna.

Obradovich, G. (2013). Coporate Governance, Institutional Ownership,and the Decision to Pay the Amount of Dividends:Evidence from USA. International Research Journal of Finance and Economics - Issue 97

Paranita. (2007). Analisis Pengaruh Insider Ownership, Kebijakan Hutang, Profitabilitas, Dan Ukuran Perusahaan Terhadap Nilai Perusahaan. ASET. 9(2), 464-493.

Purnomosidi. L., Suhadak, H. S., \& Dzulkirom. (2014). The Influences Of Company Size, Capital Structure, Good Corporate Governance, Inflation, Interest Rate, And Exchange Rate Of Financial Performance And Valueof The Company. interdisciplinary journal of contemporary research in business, 5(10).

Qureshi, M. A., Muhammad, I., \& Tanveer, A. (2012). What determines leverage in Pakistan? A panel data analysi. AfricanJournal of Business Management, 6(3), 978- 985.

Reilly, F. K., \& Brown, K. C. (2000). Investment Analysis and Portfolio Management, Fifth Edition, The Dryden Press.

Rizqia, D. A., Siti, A., \& Sumiati. (2013). Effect of Managerial Ownership, Financial Leverage, Profitability, Firm Size, and Investment Opportunity on Dividend Policy and Firm Value.Research Journal of Finance and Accounting, $4(11)$.

Rozeff, M. (1982). Growth, Beta and Agency Costs as Determinants of Dividend payout Ratios, The Journal of Financial Research, 5, 249-259. https://doi.org/10.1111/j.1475-6803.1982.tb00299.x 
Siahaan, U. M., Suhadak, S. R. H., \& Solimun. (2014). The Influence of Company Size and Capital Structure towards Liquidity, Corporate Performance and Firm Value, for Large and Small Group Companies. European Journal of Business and Management, 6(18).

Sujoko, U. S. (2007). Pengaruh Struktur Kepemilikan Saham, Leverage, Faktor Intern dan Faktor Ekstern Terhadap Nilai Perusahaan, Jurnal Ekonomi Manjemen, Fakultas Ekonomi, Universitas Petra.

Weston, F. J., \& Copeland, T. E. (1996). Financial Theory And Corporate Policy, $5^{\text {th }}$ Ed, Addison-Wesley Publishing Company, Inc, USA.

Yolana, C., \& Dwi, M. (2005). Variabel-variabel yang Mempengaruhi Fenomena Underpricing pada Penawaran Saham Perdana di BEJ tahun 1994-2001. SNA VIII 15 - 16 September 2005, pp. 538-553. Solo

\section{Copyrights}

Copyright for this article is retained by the author(s), with first publication rights granted to the journal.

This is an open-access article distributed under the terms and conditions of the Creative Commons Attribution license which permits unrestricted use, distribution, and reproduction in any medium, provided the original work is properly cited. 